\title{
Pendidikan Moral Vis A Vis Konsumerisme: Pendidikan Agama Di Desa Campurejo Panceng Gresik
}

\author{
Imam Wahyuddin \\ Dosen Fakultas Filsafat UGM \\ imam.wahyuddin@ugm.ac.id \\ Sulhatul Habibah \\ Dosen Fakultas Agama Islam UNISDA Lamongan \\ sulhatulhabibah@unisda.ac.id
}

\begin{abstract}
The existence of consumerism culture is hamful for a development rural's living such motivating people to consume more and more, beyond their a daily requirement. Seen from an economic factor, both a huge significant sea outcome and traditional market, Campurejo village was drawn an attraction to many traders. The problem is that there are many traders are danger for spritual dan social living: suggesting people to consume more and more. Such that challenge now faced by people of Campurejo, especially by education instituions Tarbiyatul Wathon, Pendidikan Muhammadiyah, TPQ Al-Hidayah and Al-Syafi'iyyah Bu Tarafah. This research combines both literary and field research. For best comprehensive result, this research equipped by some interviews and observations. The results show that moral education concept has critical implication to
\end{abstract}


defence consumerism culture, it is show that people have an abbility to control which is not to consume more and more again, beside that moral education concept increases the spritual education which perceives as the real basic morality people. This research suggest for development strategy especially for rural living people how the moral education can be seen as shield for consumerism culture.

Keywords: Moral Education, Religion Sprituality, Campurejo, Tarbiyatul Wathon, Muhammadiyah, Consumerism

Abstrak: Eksistensi budaya konsumerisme berbahaya bagi perkembangan suatu desa, masyarakat akan termotivasi untuk mengkonsumsi di luar kebutuhannya. Dilihat dari sisi perekonomian berupa hasil laut yang menjanjikan dan adanya pasar tradisional yang besar, desa Campurejo Panceng Gresik menarik banyak pendatang berdagang. Keberadaan para pedagang memicu masalah sosial baru: kehidupan di desa semakin boros mengingat suasananya dikondisikan untuk menkonsumsi. Tantangan inilah yang sedang dihadapi masyarakat desa Campurejo sebagaimana diperankan oleh lembagalembaga pendidikan setempat, di antaranya, Yayasan Pendidikan Tarbiyatul Waton, Pendidikan Muhammadiyah, TPQ Al-Hidayah dan Al-Syafi'iyyah Bu Tarafah. Penelitian ini melihat bagaimana pendidikan moral di desa Campurejo mampu menangkal dampak negatif budaya konsumerisme. Penelitian ini mengabungkan studi pustaka dan studi lapangan yang dilengkapi wawancara dan observasi. Hasil menunjukkan bahwa konsep pendidikan moral berimplikasi positif dalam upaya membendung budaya konsumerisme, hal itu ditunjukkan dengan kemampuan kontrol belanja warga desa yang tidak berlebih-lebihan, serta semakin meningkatkan kualitas pendidikan agama yang dianggap sebagai dasar moralitas sesungguhnya. Penelitian ini menyarankan kajian lebih lanjut bagi pengembang strategi desa untuk menangkal budaya konsumerisme.

Kata Kunci: Pendidikan Moral, Agama, Spritualitas, Campurejo, Tarbiyatul Wathon, Muhammadiyyah, Konsumerisme 


\section{Pendahuluan}

Konsumsi adalah bagian dari pemenuhan kebutuhan hidup manusia sehari-hari. Tidak ada salah bagi konsumsi apabila dilakukan dalam taraf wajar, namun apabila kegiatan itu dilakukan secara berlebih-lebihan: masyarakat jatuh pada budaya konsumerisme. Istilah konsumerisme dipopulerkan oleh filsuf posmodernis Perancis, Jean Baudrillard (19292007) melalui kritiknya terhadap budaya kapitalis. ${ }^{1}$

Filsuf kelahiran Reims ini menjelaskan konsumerisme adalah bentuk manusia yang berhasil dimanipulasi objek. ${ }^{2}$ Komoditas dibeli karena rayuan atau iming-iming yang ditampilkan (biasanya) melalui produk iklan. Komoditas tidak lagi dikuasai sistem produksi ala Karl Marx dulu: di mana barang dikonsumsi karena memiliki nilai guna (use-value) dan nilai tukar (exchange-value), akan tetapi barang dibeli karena nilai prestige (gengsi).

Konsumerisme menempatkan manusia bukan lagi subjek bagi dirinya, tapi sebagai "budak" dari komoditi yang belum tentu dibutuhkannya. Dalam Fatal Strategies (1983), Baudrillard menjelaskan zaman modern sekarang adalah zaman di mana obyek (komoditas) berhasil mengalahkan subyek. ${ }^{3}$ Konsumerisme berhasil mencabut manusia dalam hidupnya sebagai subyek otonom yang menentukan perjalanan sejarah.

George Ritzer menilai kritik konsumerisme Baudrillard masih relevan sampai kini. Ritzer memberikan beberapa alasan, di antaranya: konsumerisme semakin meningkat seiring dengan meningkatnya bahan produksi; alasan lain kritik budaya konsumerisme Baudrillard bersifat universal kendatipun konteksnya ditulis untuk masyarakat Perancis. ${ }^{4}$ Ritzer juga mengomentari kritikan Baudrillard berkontribusi dalam memutus orientasi produksi yang berkembang di Perancis pada saat

1 Kritikan Baudrillard dimuat dalam buku The Customer Society: Myths and Structures yang terbit pertama di Perancis pada tahun 1970.

2 Jean Baudrillard, The Customer Society: Myths and Structures (London: Sage Publications, 1998), 26.

3 Kellner Douglas, Jean Baudrillard (Stanford Philosophy Journal, 2015).

4 Jean Baudrillard, The Customer Society: Myths and Structures (London: Sage Publications, 1998), 18. 
itu. ${ }^{5}$ Pandangan ini juga dapat digunakan untuk memutus praktek konsumerisme di zaman sekarang.

Konsumsi yang tidak terkontrol merupakan salah konsumen yang tidak dapat menahan diri. Namun tidak sepenuhnya kesalahan itu dilimpahkan kepada konsumen karena ada kemungkinan dipicu faktor eksternal, salah satunya, sebagaimana disinggung Ignaz Kleden, arah pembangunan pemerintah yang berorientasi pada produksi dan peningkatan produksi. ${ }^{6}$ Pembangunan yang menitikberatkan pada produksi secara tidak langsung mengajarkan masyarakat memiliki lebih (having more), bukan mengajarkan menjadi lebih (being more). ${ }^{7}$

Indonesia untuk sekarang mesti waspada karena berdasar survey yang dikeluarkan Perusahaan Konsultan McKinsey \& Company Indonesia lima tahun lalu, masyarakat Indonesia masuk rangking kedua sebagai konsumen paling optimis setelah India. ${ }^{8}$ Di kancah internasional, Indonesia saat ini berada di 20 besar dunia berdasar faktor konsumsi pribadi. Sebagian besar sektor yang dikonsumsi adalah produk finansial dan produk sektor hiburan. Kemungkinan tahun ini dan tahun-tahun berikutnya peringkat Indonesia bertambah melihat gaya hidup komsumsi tambah melonjak, yang di antara penyebabnya, dipicu maraknya belanja online atau online shop.

Kebiasaan buruk konsumerisme Indonesia mendatangkan kerusakan di pemerintah. Di tingkat nasional, konsumerisme telah merusak sebagian moralitas pejabat negara. Pengamat politik dari Universitas Warmadewa Denpasar, Dr. I gede Wayan Saucana menyebut konsumerisme di kalangan pejabat dapat memicu terjadinya tindak korupsi. ${ }^{9}$ Korupsi terjadi karena tuntutan gaya hidup yang tinggi sementara pendapatan yang besar dirasa masih tidak mencukupi.

5 Ibid., 19.

${ }^{6}$ Ignas Kleden, Sikap Ilmiah dan Kritik Kebudayaan (Jakarta: LP3ES, 1987), 263.

7 Ibid., 262.

${ }^{8}$ Lihat:https://ekonomi.kompas.com/read/2015/01/27/1730011/Indonesia. Peringkat.Kedua.Dunia.sebaga.Konsumen.Teroptimistis

9 Koran Republika, edisi 26 Oktober 2017. 
Budaya konsumerisme juga tidak menutup kemungkinan merusak kehidupan di desa-desa sejalan dengan perkembangan dunia informasi (iklan), kecanggihan teknologi dan kebijakan peningkatan produksi. Hal inilah yang sedang terjadi di desa Campurejo Panceng Gresik. Desa di pesisir Pantura yang berbatasan dengan kabupaten Lamongan yang sebagian penduduknya didominasi nelayan, pedagang dan pekerjaperantauan ke luar negeri (TKI), termasuk desa yang pertumbuhan ekonominya sangat cepat dibandingkan desa-desa di sekitarnya.

Hasil laut menyumbang kemakmuran bagi ekonomi warga Campurejo Panceng Gresik. Sejak berdirinya Pusat Pelelangan Ikan (PPI), produksi ikan semakin menjanjikan meskipun sebagian besar bukan dari nelayan lokal. Hasil ini didapat dari kapal dari luar daerah yang sengaja bersandar di PPI Campurejo. Nelayan lokal sangat menyukupi untuk konsumsi warga sekitar, bahkan lebih. Menurut Dinas Kelautan Peternakan dan Perikanan (DKPP) Gresik, hasil perikanan di Gresik naik dari 94 ribu ton menjadi 98 ribu ton di tahun 2014. ${ }^{10}$ Campurejo menyumbangkan 15 persen hasil perikanan di kota Gresik.

Ketika pertumbuhan ekonomi meningkat, banyak pendatang merantau di Campurejo. Sebagai kebangkitan ekonomi mikro, perkembangan ini tentu baik, tetapi dengan banyaknya para pendatang, meyisahkan masalah sosial bagi masyarakat lokal. Sepanjang jalan utama penghubung desa dipadati penjual makanan dari sore hingga malam hari. Keberadaan penjual dengan skala massif menarik penduduk sekitar untuk menkonsumsi.

Dampak negatif dari praktik konsumsi yang berlebih-lebihan ini, masyarakat selalu kekurangan anggaran belanja terutama bagi para ibu rumah tangga. Dampak negatif lain di sore hari yang biasanya digunakan mengaji Taman Pendidikan Al-Qur'an (TPQ) bagi anak-anak kecil mendapat tantangan tersendiri dengan keberadaan dan pengaruh para pedagang tersebut.

Apabila perkembangan ini terus dibiarkan maka masyarakat desa Campurejo akan mengalami kerugian: pertama, di mana seharusnya

${ }^{10}$ Lihat: http://disperikanan.gresikkab.go.id/beritadetail.php?ID=20 
masyarakat hidup tercukupi dengan sumberdaya dan ekonomi yang tersedia di desa justru malah kekurangan karena motivasi belanja yang tinggi; kedua, hilangnya nilai-nilai spiritual agama karena tergerus budaya konsumerisme dan hedonisme; ketiga, kehidupan di desa menjadi sangat keras karena desakan tuntutan ekonomi yang berdampak hilangnya wisdom lokal seperti nilai keakraban, toleransi, keguyuban dan lain sebagainya.

Menariknya di tengah meluasnya budaya konsumerisme tersebut, masyarakat Campurejo berusaha menetralisir pengaruh konsumerisme agar tidak mendominasi. Peran itu diambil oleh lembaga-lembaga pendidikan agama seperti Yayasan Tarbiyatul Wathon dan lembaga pendidikan Muhammadiyah Campurejo. Peran yang sama diteladankan di lembaga pengajaran Al-Qur'an di mushollah-mushollah kecil, seperti Mushollah Al-Hidayah Campurejo. Selain lembaga di atas, organisasi kemasyarakatan berbasis keagamaan seperti Jama’ah Nariyah, Muslimat, Fatayat, remaja masjid dan mushollah turut berperan dalam membangun moralitas warga Campurejo. Berangkat dari sini peneliti tertarik mengkaji apa sejatinya pelajaran moral yang dikembangkan oleh lembaga-lembaga tersebut, terutama dalam membendung budaya konsumerisme di Campurejo.

\section{Konsep Pendidikan Moral}

Pendidikan moral sesuatu paling penting tetapi juga paling kompleks dijelaskan. ${ }^{11}$ Satu pengandaian dalam buku Moral Education: Theory and Practices menarik dikutip di sini: pendidikan moral yang diberikan guru tetap berdampak meski jam pelajaran di kelas telah usai. ${ }^{12}$ Pendidikan moral memiliki jangka mendidik lebih panjang daripada pendidikan formal di kelas yang dibatasi oleh durasi waktu/jam.

Pendidikan moral kerap diandaikan sama dengan pendidikan agama. Sekilas memang ada benarnya, akan tetapi jika dilihat lebih mendalam

\footnotetext{
${ }^{11}$ Downey and Kelly, Moral Education: Theory and Practices, (London: Harper \& Row Publisher, 1982), viii.

${ }^{12}$ Ibid., hal. vii.
} 
keduanya dapat dibedakan: pendidikan agama berisi cara dan bagaimana memahami ajaran-ajaran agama, sedang pendidikan moral berisi ajaranajaran moral tentang perilaku kebajikan. Agama dapat menyumbang nilainilai moral tetapi tidak dapat diklaim secara langsung bahwa pendidikan agama adalah pendidikan moral. Kendatipun dapat dibedakan, sebagian pengamat melihat pendidikan agama secara mendasar juga mencakup pendidikan moral. Pendidikan agama dapat menjadi pendidikan moral apabila dalam pengajaran agama dibarengi peresapan mendalam tentang makna (nilai moral) di balik ajaran suatu agama. Sebagaimana dinyatakan dalam peryataan berikut: if we cannot justify teaching the doctrinal aspects of religion, then we cannot justiry teaching the moral precepts that are based on them. ${ }^{13}$

Kendati moralitas agama itu penting tetapi jangan sampai menjadi authoritarian morality, seperti dorongan berbuat baik karena tuntutan agama. ${ }^{14}$ Susah membayangkan moralitas tanpa dalih agama (Allah), akan tetapi perspektif ini sudah dipikirkan matang-matang oleh filsuf Jerman Immanuel Kant (1727-1804). Agar agama tidak menjadi authoritarian morality, moralitas dilakukan demi moralitas itu sendiri atau disebut keyakinan moral (moral faith). ${ }^{15}$ Kant menyatakan: "belief in God is grounded in the moral consciousness rather than the moral law on belief in God." Manusia memang tidak dapat menyingkirkan moralitas, jika hidup tanpa moral maka manusia jatuh di level of animal existence. Apa pasal pendidikan moral itu penting?

Sejatinya manusia memiliki dua aspek dhahir dan batin, pendidikan moral pun demikian. Dilihat dari luar, moralitas menyediakan cara bergaul dengan orang lain, dan dari dalam moralitas adalah cara bergaul dengan dirinya sendiri. ${ }^{16}$ Thomas Wren menulis kedua aspek tersebut (luar dan

${ }^{13}$ Ibid., 5-6.

${ }^{14}$ Ibid., 7.

${ }^{15}$ Frederick Copleston, SJ, A History of Philosophy; Modern Philosophy from the French Enlightenment to Kant, vol. VI, (New York: Image Book, 1994), 317.

${ }^{16}$ Thomas Wren dalam Larry P. Nuccy dan Darcia Narvaez (Editor), Handbook Pendidikan Moral dan Karakter Pen. Baehaqi dan Widowatie (Bandung: Nusamedia, 2014), 14. 
dalam) mengakar dalam tradisi Buddha dan Yunani. Meditasi Buddha di bawah pohon Bodhi mendapatkan pencerahan melalui pengosongan diri (penjernihan hati), sementara para filsuf Yunani memahami pencerahan sebagai kebijaksanaan shopia. ${ }^{17}$

Pelajaran dari Buddha dan filsafat Yunani menunjuk arti penting pendidikan untuk merubah perilaku manusia menjadi lebih baik. Baik pengosongan diri (penjernihan ego) maupun pencerahan melalui kebijaksanaan sophia bermanfaat bagi manusia. Demikianlah pendidikan berusaha menempah manusia menjadi lebih baik (lebih manusiawi): manusia yang sadar akan dirinya sekaligus memahami lingkungan sekitar.

Sastrapratedja menjabarkan arah pendidikan sebagai usaha pemberdayaan manusia melalui tiga hal: pertama, daya untuk berbuat (powerto) artinya pendidikan mendorong anak didik berani melakukan sesuatu atau kreatif; kedua, kekuatan bersama (power-with) artinya pendidikan yang membangun solidaritas bersama dan memiliki kepedulian terhadap lingkungan sekitar; dan ketiga, kekuatan dari dalam (power-within) artinya kekuatan spiritual yang membuat manusia lebih manusiawi. ${ }^{18}$

Terkait dengan pendekatan Islam, pendidikan morlal sudah inhern karena Islam tidak mengenal pemisahan antara agama dan dunia seperti pengalaman di Barat. Prof. Dr. Achmadi menyebut nilai inti pendidikan Islam adalah humanisme teosentris: pandangan kemanusian dalam bingkai keimanan kepada Allah. ${ }^{19}$ Seluruh kehidupan manusia berpusat kepada Allah (tauhid) dan berujung kemaslahatan manusia, karena itu iman dan amal shaleh bagaikan dua sisi mata uang yang tidak dapat dipisahkan. ${ }^{20}$

Penyebaran Islam di Indonesia yang didominasi tasawwuf menjadikan corak pendidikan di pesantren lebih asketis. ${ }^{21}$ Selain mempelajari keilmuan Islam tradisional, pesantren menjadi pusat gerakan tasawwuf, ${ }^{22}$ hal itu

\section{$17 \quad$ Ibid., 15.}

${ }^{18}$ M. Sastrapratedja, SJ., Pendidikan sebagai Humanisasi (Jakarta: Pusat Kajian Filsafat dan Pancasila, 2013), 14-15.

${ }^{19}$ Achmadi, Ideologi Pendidikan Islam (Jakarta: Kencana, 2010), 23.

${ }^{20}$ Ibid., 24-25.

${ }^{21}$ Abdurrahman Wahid, Bunga Rampai Pesantren (Jakarta: Dharma Bakti, 1984), 17.

${ }^{22}$ Syahrul A'dam dalam Suwito dan Fauzan (Editors), Sejarah Sosial Pendidikan Islam 
dapat ditemukan dalam pembelajaran tiga pilar ajaran Islam: Islam, iman dan ihsan. Ketiganya kalau ditarik dalam bidang ilmu pengetahuan akan melahirkan: syariah, tauhid dan akhlaq. Inilah cara penempaan moral dalam pendidikan Islam sebagaimana di pesantren. Warisan pendidikan pesantren telah menyebar ke desa-desa, bentuk paling kongkritnya adalah pendidikan formal madrasah dan pendidikan non formal seperti TPA atau kegiatan mengaji Al-Qur'an di musholah. Spirit pembelajaran agama dengan pendekatan sufistik mewarnai dinamika pendidikan di sekolah madrasah. Sementara madrasah sendiri secara yuridis sudah diakui sebagai lembaga pendidikan agama, sebagaimana tercantum dalam Surat Keputusan Bersama (SKB) Tiga Menteri Tahun 1975, Bab I Pasal 1. ${ }^{23}$

Konsepsi pendidikan moral sebagaimana dirumuskan Downey dan Kelly dikenali hasilnya sebagai berikut: pertama, bagaimana seorang dapat berpikir secara moral untuk dirinya sendiri, artinya dapat mengetahui ini yang baik dan yang lain tidak baik; kedua, kemampuan seseorang menghargai nilai-nilai moralitas seperti kejujuran, kesopanan, kepatuhan dan lain sebagainya; ketiga, menyadari dengan sepenuh hati konsekuensi dari perbuatannya. ${ }^{24}$

Howard Kirschenbaum melihat cara yang paling komprehensif dalam menanamkan pendidikan moral melalui empat hal: kontain, metode, sekolah, dan masyarakat. ${ }^{25}$ Dari sisi kontain sudah tidak dipertanyakan lagi bahwa madrasah mengajarkan pendidikan yang hendak membentuk akhlaq islami, dari sisi metode pengajaran di madrasah mengedepankan etiked dan menunjukkan penghargaan terhadap ilmu pengetahuan, dari sisi sekolah memang sedari awal madrasah adalah menekankan pendidikan agama yang fokus pada pembentukan moral, dan dari sisi masyarakat sudah hampir dipastikan juga di Campurejo banyak organisasi

(Jakarta: Kencana, 2015), 276.

${ }^{23}$ Haidar Putra Daulay, Pendidikan Islam dalam Sistem Pendidikan Nasional (Jakarta: Kencana, 2012), 57.

${ }^{24}$ Downey and Kelly, Moral Education: Theory and Practices, (London: Harper \& Row Publisher, 1982), 30-31.

${ }^{25}$ Howard Kirschenbaum, 100 Ways to Enhance Values and Morality in School and Youth Setting (Boston: Allyn \& Bacon, 1995), 9-10. 
masyarakat berbasis keagamaan yang tetap peduli pada pendidikan moral bagi masyarakat.

Pilihan mana yang hendak dijadikan pijakan tentang pendidikan moral? Sebelum sampai pada perumusan itu lebih baik melihat dua konsep pendidikan moral menurut Islam dan pandangan Aristoteles. Islam menjadikan tauhid titik tolak pendidikan, di mana pendidikan digunakan untuk mengenal Allah dan sebagai dampaknya manusia menjadi wakil Allah di bumi. Pendidikan (tarbiyah) dengan demikian bermakna ibadah dan oleh karena itu tanggung jawab pendidikan tidak hanya kepada manusia melainkan harus dipertanggungjawabkan kepada Allah. ${ }^{26}$ Dalam filsafat Yunani, seperti diteorikan Aristoteles, kebijakan praktis (phronesis) pada diri seseorang selalu didahului kebijakan teoritis (poesis). Nilai-nilai teoritis keutamaan harus mendasari perbuatan praktis manusia. ${ }^{27}$ Contoh paling sederhana ialah: seseorang tidak dapat berprilaku saleh sebelum dalam pikirannya telah terlebih dahulu memiliki konsepsi atau pikiran apa itu kesalehan.

Kombinasi kedua sudut pandang antara Islam dan Aristoteles dapat dipertemukan, tentu saja kebajikan teoritis menurut Aristoteles tidak lain di dalam Islam adalah aspek tauhid itu sendiri, sedangkan kebajikan praksis adalah bentuk perbuatan kebaikan (amal shaleh). Manusia yang mengenal Allah dalam hidupnya akan menjalani hidup penuh tanggung jawab. Amal shaleh merupakan bentuk kongkretisasi iman kepada Allah. Sampai di sini pendidikan moral dapat dikenali gejalanya, pendidikan moral tak lain merupakan kebijaksanaan praktis yang dapat diidentifikasi: persepsi, pertimbangan (perbuatan-keputusan), berpikir kolaboratif dan pembiasaan. ${ }^{28}$

Pertama, persepsi: kemampuan penalaran terhadap situasi yang kongkret, keutamaan tidak didapat melalui pilihan tetapi dengan mengenali keadaan yang relevan pada tujuan tertentu. Kedua, pertimbangan

\footnotetext{
${ }^{26}$ Achmadi, Ideologi Pendidikan Islam (Yogyakarta: Pustaka Pelajar, 2010), 29-30.

27 Thomas Wren dalam Larry P. Nuccy dan Darcia Narvaez (Editor), Handbook Pendidikan Moral dan Karakter Pen. Baehaqi dan Widowatie (Bandung: Nusamedia, 2014), 24.

${ }^{28}$ Ibid., 24-25.
} 
(perbuatan-keputusan): tahapan ini merupakan tindakan yang dilakukan setelah melakukan persepsi. Ketiga, berpikir kolaboratif: tahapan ini mengandaikan bahwa kebajikan tidak dilakukan untuk kepentingan diri sendiri, melainkan untuk kepentingan bersama karena pada dasarnya manusia adalah zoon politikon, manusia adalah makluk sosial dan tidak dapat hidup tanpa bantuan orang lain (komunitas). Keempat, pembiasaan: kebaikan tidak akan melekat pada diri seseorang kalau tidak ada upaya pembiasaan seperti memberlakukan disiplin, pengajaran, bimbingan dan hal-hal lain seperti yang dilakukan dalam pendidikan formal.

\section{Aktualisasi Pendidikan Moral di Masyarakat}

Pola penerapan pendidikan moral di desa Campurejo Panceng tentunya perlu penekanan pada unsur-unsur penting di masyarakat, sehingga kesadaran masyarakat akan pentingnya mengetahui dan membedakan antara kebutuhan dan keinginan terpenuhi. Kontrol yang dapat diterapkan melalui beberapa unsur berikut ini:

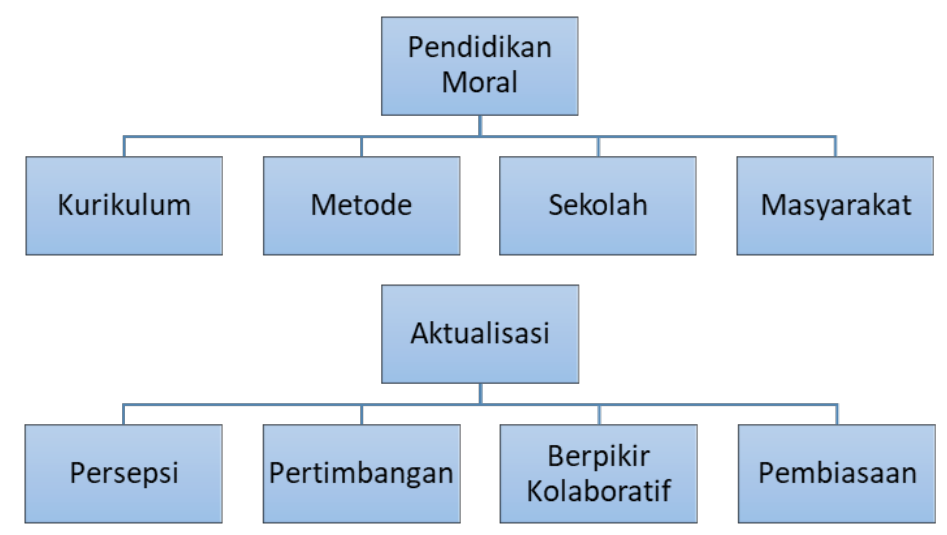

Pendidikan moral dalam tulisan ini dapat ditanamkan, sebagaimana pendapat Howard Kirschenbaum, melalui empat hal, yaitu: kurikulum, metode, sekolah dan masyarakat. Kemudian dalam tahap aktualisasinya, pendidikan moral dapat dikenali melalui empat kebijaksanaan praksis sebagaimana rumusan Aristoteles (yang dikembangkan oleh Nancy Sherman dalam Thomas Wren) yaitu: persepsi, pertimbangan, berpikir kolaboratif dan pembiasaan. Keempat unsur ini menjadi tolak ukur bagi aktualisasi pendidikan formal di masyarakat desa Campurejo Panceng 
Gresik. Setelah mengetahui hasil dari pendidikan moral maka langkah selanjutnya bagaimana peran pendidikan moral tersebut dalam menangkal budaya konsumerisme di desa tersebut.

\section{Pendidikan Moral di desa Campurejo}

\section{Profil Desa Campurejo}

Desa Campurejo terletak di pesisir pantai utara kecamatan Panceng Kabupaten Gresik. Campurejo juga berbatasan dengan Kabupaten Lamongan. Secara georafis desa tersebut sangat strategis, karena di sana ada TPI (Tempat Pelelangan Ikan), kapal-kapal besar dari pulau seberang juga singgah di sana, sehingga menjadi mata rantai pergerakan ekonomi khususnya perdagangan.

Mayoritas pencaharian warga sebagai nelayan dan pedagang, sebagian ada yang menjadi PNS, guru, kuli bangunan dengan upah harian, TKI di negeri Jiran dan lain sebagainya. Sentra perdagangan menjadi modal utama kemajuan perekonomian di sana, karena selain TPI, ada pasar yang cukup besar, sehingga banyak pula warga dari desa lain bahkan kecamatan yang lain berdagang dan belanja di pasar tersebut.

Seiring perkembangan zaman, kapal-kapal pesiar dan para nelayan warga di sana banyak menghasilkan ikan, sehingga semakin banyak masyarakat dari luar yang mengenal desa Campurejo. Secara bertahap namun terbilang cepat desa Campurejo yang awalnya masih banyak lahan-lahan kosong, sekarang sudah penuh dengan bangunan rumah dan tempat usaha. Banyak warga dari luar seperti dari Lamongan, Bojonegoro, Madura, Madiun, Tuban bahkan dari Solo datang ke sana untuk berdagang. Tempat berdagang mereka di pinggir jalan panjang antara desa Campurejo dan Dalegan.

Pedagang di sana mulai dari pedagang makanan, perabotan rumah, baju, dan lain sebagainya. Tempatnya juga berderet di sepanjang jalan. Apalagi desa sebelah Campurejo yaitu desa Dalegan ada wisata "Pasir Putih" banyak pula wisatawan dari luar kabupaten ke sana, sehingga semakin menarik banyak masyarakat luar daerah untuk berdagang di Campurejo. 


\section{Pendidikan Moral di desa Campurejo}

Secara konseptual lembaga pendidikan memainkan peran penting memperbaiki moralitas anak didik, secara khusus, dan mayarakat secara umum. Pendidikan di desa Campurejo didominasi lembaga pendidikan agama, setidaknya terdapat dua afiliasi instansi keagamaan besar: sekolah afiliasi Nahdlatul Ulama (Tarbiyatul Wathon) dan sekolah afiliasi Muhammadiyyah. Dua lembaga ini secara intens menjalankan fungsinya memperkuat dasar-dasar pelajaran moral keagamaan. Selain pendidikan formal, Campurejo juga berdiri lembaga pendidikan non formal seperti TPQ (Taman Pendidikan Al-Qur'an), di antaranya, musholla Al-Hidayah, TPQ Al-Syafi'iyyah Bu Tarafah.

Bagaimanapun kurikulum menentukan arah pembelajaran suatu sekolah. Sejauh melihat muatan kurikulum di kedua sekolah Tarbiyatul Wathon dan Muhammadiyah, tentunya pembelajaran agama menempati posisi paling dominan. Catatan diberikan khusus untuk Tarbiyatul Wathon di mana mata pelajaran keagamaan di sana hampir mencapai $80 \%$ dari total keseluruhan mata pelajaran yang dipelajari. Mata pelajaran keagamaan meliputi, di antaranya, pendidikan Al-Qur'an dan Hadits, ilmu faraid, akidah akhlaq, bahasa Arab, fikih, dan lain sebagainya. Kendatipun mata pelajaran agama lebih dominan namun bukan berarti mata pelajaran di luar itu diabaikan.

Selain kurikulum, metode juga menentukan keberhasilan pembelajaran di sekolah. Barangkali seperti umumnya sekolah-sekolah negeri di Indonesia, metode pembelajaran di kelas berlangsung sebagaimana mestinya. Namun harus diakui pembelajaran di sekolah-sekolah berbasis keagamaan sebagaimana Tarbiyatul Wathon dan Muhammadiyah di Campurejo, beberapa pelajaran ditekankan aspek hafalan khususnya pada mata pelajaran yang terkait dengan pengamalan ibadah seperti fikih, AlQur'an dan al-hadits, bahkan bahasa Arab pun diterapkan dengan hafalan.

Penekanan aspek kognitif sekolah berbasis keagamaan barangkali porsinya jauh lebih besar dari pada sekolah di luar basis tersebut. Sejalan dengan itu, aspek keagamaan yang diajarkan memantik etiked siswa lebih peka seperti ditujukan sikap hormat pada guru dengan mencium tangan atau mengucap salam saat bertemu di luar kelas. Secara tidak langsung 
prinsip moralitas tertanam dalam perilaku siswa baik saat di dalam kelas maupun di luar kelas. Dalam hal ini selain aspek kognitif, pembelajaran di sekolah Tarbiyatul Wathon dan Muhammadiyah di Campurejo juga menyentuh afektif siswa.

Keberadaan sekolah sebagai elemen yang ketiga dalam konsep pendidikan moral di desa Campurejo harus diberikan perhatian lebih. Mengapa demikian? Sejauh ini Tarbiyatul Wathon menjalankan fungsinya sebagai lembaga pendidikan yang penting untuk dicontoh, terutama dalam menanamkan moralitas pada para siswanya. Hal itu ditempuh dengan adanya Madrasah Diniyyah yang fokus pada mata pelajaran agama. Jika dalam sekolah formal masih menyertakan mata pelajaran eksakta, sosial, dan humaniora, maka dalam Madrasah Diniyyah yang biasanya dilaksanakan pada malam hari setelah Maghrib, hanya mengajarkan agama dan kitab-kitab kuning warisan ulama Muslim klasik.

Bagaimanapun tradisi ini tidak diikuti sekolah Muhammadiyah yang memang sedari awal fokus pada modernisasi birokrasi. Adapun Nahdlatul Ulama telah memilih mengakar pada tradisi klasik sebagaimana terangkum dalam adagium: al-muhâfadzah 'alâ al-qadîm al-shâlih wa alakhdz-u bi al-jadîd al-asla $\underline{h}$ atau menkonservasi tradisi yang baik sekaligus mengadopsi yang lebih baik lagi. Kendatipun demikian aspek konservasi di lingkungan Nahdlatul Ulama ternyata jauh lebih dominan sementara aspek adopsi kurang begitu diperhatikan. Keadaan ini berbalik dengan Muhammadiyah yang cenderung dominan di adopsi budaya modern sementara aspek konservasi tradisi klasik kurang begitu menonjol di dalamnya.

Elemen terakhir pendidikan moral dalam penelitian ini ialah masyarakat. Bagaimanapun keberadaan masyarakat menjadikan individu perorangan menjadi berarti. Bukankah dalam tradisi filsafat seperti dikonsepsikan oleh Aristoteles: manusia adalah makhluk politik atau zoon politikon artinya kesempurnaan manusia hanya didapat ketika hidup dalam koloni atau komunitasnya. Beruntung masyarakat Campurejo dikarunia kesadaran mendalam tentang pentingnya benteng spritualitas bagi anak didik. Secara keseluruhan warga Campurejo mendukung tercipta dan terpeliharanya nuansa moralitas di lingkungan internal desa. 
Apa pasal warga Campurejo menaruh perhatian lebih pada pendidikan moral? Setidak-tidaknya para warga peduli dengan pendidikan AlQur'an khususnya kepada para anak usia dini. Kepedulian itu terlihat dari aktivitas di dua TPQ yaitu di Mushollah Al-Hidayah dan TPQ AlSyafi'iyyah Bu Tarafah. Tidak heran aktivitas setiap sore banyak anak kecil pulang mengaji, pemandangan itu mudah ditemukan di gang-gang desa Campurejo. Pendidikan Al-Qur'an merupakan dasar pembentukan karakter Islam yang kelak mewarnai perilaku anak ketika dewasa. Tujuan pendidikan tersebut tidak lain adalah untuk membentuk moralitas anak sejak dini.

\section{Aktualisasi Melawan Konsumerisme}

Aktualisasi pendidikan moral di desa Campurejo mengikuti empat rumusan kebijakan praksis Aristoteles sebagaimana dikembangkan oleh Nancy Sherman yang telah dijelaskan di atas:

Pertama, persepsi, kemampuan penalaran terhadap situasi yang kongkret, keutamaan tidak didapat melalui pilihan tetapi dengan mengenali keadaan yang relevan pada tujuan tertentu. Dalam hal ini masyarakat Campurejo mengutamakan basis pendidikan karakter daripada memilih pemenuhan kebutuhan sekunder lain. Pemilihan tersebut atas sebuah alasan bahwa keutaman moral jauh lebih penting. Moralitas merupakan pemenuhan hidup makhluk yang berakal budi. Atas dasar ini masyarakat Campurejo tidak mudah terbawa arus konsumerisme yang berlebihlebihan;

Kedua, pertimbangan yang dilakukan setelah menentukan sikap atau menentukan pilihan. Pendidikan moral lebih mengutamakan dimensi spritual ditempuh dengan pembelajaran dasar agama. Campurejo dapat menjadi percontohan di mana sekolah atau lembaga pendidikan dan masyarakat berperan aktif mewujudkan cita-cita mulia tersebut. Lembaga pendidikan seperti Tarbiyatul Wathon dan Muhammadiyah sedari awal konsisten dengan pendidikan agama. Dilihat dari keseluruhan warga Campurejo lebih memilih pendidikan agama daripada sekolah di luar tradisi itu; 
Ketiga, berpikir kolaboratif, tahapan ini merupakan pemenuhan manusia sebagai zoon politikon, manusia adalah makluk sosial dan tidak dapat hidup tanpa bantuan orang lain (komunitas). Kesadaran akan pentingnya pendidikan moral di desa Campurejo bukan menjadi tanggung jawab lembaga atau guru saja, melainkan menjadi perhatian seluruh elemen masyarakat desa. Sebuah contoh keberadaan TPQ, sebenarnya didirikan atas kesadaran warga pentingnya pembelajaran agama. Eksistensi TPQ Al-Hidayah maupun TPQ Al-Syafi'iyyah Bu Tarafah merupakan manifestasi perjuangan warga agar masyarakat sadar (moralitas) agama;

Keempat, pembiasaan: bagaimanapun kebaikan tidak akan melekat pada diri seseorang kalau tidak ada upaya pembiasaan. Dalam dunia pendidikan pembiasaan diwujudkan dengan formalitas atau kegiatan prosedural yang dalam bahasa sederhananya: rutinitas. Pembiasaan tersebut sejauh ini dikawal baik oleh lembaga pendidikan yang bersangkutan maupun oleh masyarakat itu sendiri. Konsistensi pembelajaran di sekolah maupun TPQ kerap dipertahankan sebagai bagian yang menyatuh dalam kehidupan masyarakat. Ketersediaan lembaga pendidikan baik formal maupun informal serta partisipasi aktif masyarakat telah menunjang pelaksanaan pendidikan moral di Campurejo.

Harus diakui bahwa konsumerisme di desa Campurejo menopang kebutuhan hidup sehari-hari warganya, menginggat Campurejo menjadi pusat perekonomian di antara desa-desa di sekitarnya. Namun demikian, masyarakat Campurejo telah menyadari pentingnya dimensi spritual. Dampak positif dirasakan masyarakat mampu mengontrol pembelanjaan sehari-hari. Hal ini terlihat dari ekonomi di Campurejo masih berjalan dengan baik sebagaimana mestinya, di satu sisi, sementara dinamika spritualitas yang mencerminkan pendidikan moral tetap terjaga dan terpelihara, di sisi lain.

Bagaimanapun aktualisasi pendidikan moral dalam melawan konsumerisme di Campurejo sebagaimana ditunjukan dalam empat hal di atas menegaskan tesis Weber: bahwa aspek spritualis ternyata masih berpengaruh dan relevan saat ini. Dulu klaim materialisme historis Karl Marx menyatakan hanya materi yang mampu merubah sejarah, namun klaim tersebut secara eksplisit maupun implisit disanggah Weber dalam 
penelitian tentang The Protestant Ethic and Spirit of Capitalism. ${ }^{29}$ Menurut Weber budaya kapitalisme di Eropa diinisiasi gerakan asketisme batin. Materialis-determinis bukan satu-satunya penentu perubahan. Weber membuktikan idealis-determinis sebagaimana asketisme etika Protestan adalah kekuatan yang perlu dipertimbangkan.

\section{Penutup}

Desa Campurejo menjadi percontohan bagi desa-desa lain menghadapi budaya konsumerisme yang telah masuk ke desa-desa. Hasil penelitian menunjukkan bahwa konsep pendidikan moral berimplikasi positif dalam upaya membendung budaya konsumerisme, hal itu ditunjukkan dengan kemampuan kontrol belanja warga desa yang tidak berlebih-lebihan, serta semakin meningkatkan kualitas pendidikan agama yang dianggap sebagai dasar moralitas sesungguhnya.

Pendidikan moral yang berbasis pengajaran agama di desa Campurejo mengafirmasi agama sejauh ini memainkan peran penting dalam menangkal arus negatif modernitas, yaitu budaya konsumerisme yang berlebihlebihan. Percontohan Campurejo dapat dikembangkan lebih jauh lagi terutama untuk mengenalkan pemahaman agama sejak dini sebagai upaya menepis dampak negatif konsumerisme yang kini semakin tak terbendung.

Kendatipun penelitian ini menitikberatkan pada peran pendidikan moral sebagaimana dijalankan di level pendidikan formal dan nonformal, tentunya pendidikan moral berbasis agama banyak dipengaruhi faktorfaktor lain yang belum dapat diungkap penelitian ini. Penelitian ini dengan sendirinya menjadi awal bagi penelitian berikutnya untuk mengembangkan penelitian yang telah ada ataupun untuk menemukan faktor lain yang belum terungkap.

${ }^{29}$ Tom Campbell, Seven Theories of Human Society (Oxford: Claredon Press, 1981), 184 . 


\section{Daftar Pustaka}

Achmadi. Ideologi Pendidikan Islam, Yogyakarta: Pustaka Pelajar, 2010.

Baudrillard, Jean. The Customer Society: Myths and Structures, London: Sage Publications, 1998.

Campbell, Tom. Seven Theories of Human Society, Oxford: Clarendon Press, 1981.

Copleston, Frederick, SJ. A History of Philosophy: Modern Philosophy from

French Enlightenment to Kant, Image Book, New York, 1994.

Dauly, Haidar Putra. Pendidikan Islam dalam Sistem Nasional di Indonesia, Jakarta: Kencana, 2012.

Downey, Meriel dan Kelly, AV. Moral Education: Theory and Practices, London: Harper \& Row Publisher, 1982

Featherstone, Mike. Consumer Culture and Postmodernism, London: Sage Publications, 1991.

https://ekonomi.kompas.com/read/2015/01/27/1730011/Indonesia. Peringkat.Kedua.Dunia.sebagai.Konsumen.Teroptimistis (diakses 11 April 2018).

http://disperikanan.gresikkab.go.id/beritadetail.php?ID=20 (diakses 12 April 2018).

Kaelan. Metode Penelitian Kualitatif Bidang Filsafat: Paradigma bagi Pengembangan Penelitian Interdisipliner Bidang Filsafat, Budaya, Sosial, Semiotika, Sastra, Hukum dan Seni, Yogyakarta: Penerbit Paradigma, 2005.

Kellner, Douglas. "Jean Baudrillard", The Stanford Encyclopedia of Philosophy (Winter 2015 Edition), Edward N. Zalta (ed.), URL = https://plato.stanford.edu/archives/win2015/entries/baudrillard/ (diakses pada 24 Mei 2017).

Kirschenbaum, Howard. 100 Ways to Enhance Values and Morality in Schools and Youth Settings, Boston: Allyn \& Bacon, 1995

Kleden, Ignaz. Sikap Ilmiah dan Kritik Kebudayaan, Jakarta: LP3ES, 1987. Koran Republika (26 Oktober 2017). 
Nucci, Larry P. dan Narvez, Darcia. Handbook Pendidikan Moral dan Karakter, Penerjemah Imam Baehaqi dan Derta Sri Widowatie, Bandung: Nusamedia, 2014.

Sastrapratedja, SJ., M. Pendidikan sebagai Humanisasi, Jakarta: Pusat Kajian Filsafat dan Pancasila, 2013.

Suwito dan Fauzan. Sejarah Sosial Pendidikan Islam, Jakarta: Kencana, 2015.

Wahid, Abdurrahman. Bunga Rampai Pesantren, Jakarta: Dharma Bakti, 1984. 
